\title{
Application of Criminal Sanction Policy Against Crime Perpetrators of Domestic Violence
}

\author{
Danu Anindhito Kuncoro Putro ${ }^{1}$ and Ira Alia Maerani ${ }^{2}$
}

Abstract. The research titled: Application of Criminal Sanction Policy Against Crime Perpetrators of Domestic Violence, Problems of this research are: 1) How the policy formulation of the crime of domestic violence? 2) How can the application of criminal sanctions against perpetrators of criminal acts of violence in the home? 3) Constraints are faced judges in the application of criminal sanctions against perpetrators of the crime of domestic violence and efforts to overcome it? The method used in this research using normative research is descriptive qualitative analysis. This study is a literature. The results of the study using sociological juridical concluded that: 1) Policy formulatif against the crime of domestic violence set out in Chapter VIII of Act No. 23 of 2994 Article 44 of physical violence, Article 45 of the violence phisikis, Articles 46, 47, 48 on sexual violence and Article 49 of Neglection. 2). The application of criminal sanctions against perpetrators of criminal acts of domestic violence committed by the judge after going through the process of proving to the charges the prosecutor. Starting from proven facts deeds of witnesses, then the fact juridical considerations and ease further aggravating the new verdict. 3) Constraints faced by judges in the application of criminal sanctions against perpetrators of criminal acts of domestic violence are: a. ) The absence of witnesses cause hearing be postponed, so that the proceedings so that the proceedings be longer than scheduled. b.) The absence attorneys also cause hearing was postponed from the trial process has gone backwards longer than scheduled. c.) The absence of a post mortem result in the judge adjourned the hearing, to include post mortem beforehand. d.) The judge is hard to prove because there were no witnesses who saw directly, and also sometimes victims of domestic violence and perpetrators still love each other, so that judges convict when the weight will result in divorce. e) The absence attorneys also cause hearing was postponed from the trial process has gone backwards longer than scheduled. f.) The absence of a post mortem result in the judge adjourned the hearing, to include post mortem beforehand. g.) The judge is hard to prove because there were no witnesses who saw directly, and also sometimes victims of domestic violence and perpetrators still love each other, so that judges convict when the weight will result in divorce. The absence attorneys also cause hearing was postponed from the trial process has gone backwards longer than scheduled. h.) The absence of a post mortem result in the judge adjourned the hearing, to include post mortem beforehand. i.) The judge is hard to prove because there were no witnesses who saw directly, and also

\footnotetext{
${ }^{1}$ Police in Polda East Java email: danuanindito@gmail.com

${ }^{2}$ Lecturer of Faculty of Law UNISSULA Semarang
} 
sometimes victims of domestic violence and perpetrators still love each other, so that judges convict when the weight will result in divorce.

Keywords: Legal Policy; Crime; Domestic Violence.

\section{Introduction}

Law on the Elimination of Domestic Violence aims to provide protection to victims of violence in the household. But in reality, the protection afforded insufficient, particularly because of sanctions for offenders are not appropriate. Seen from the point of criminal policy, the uncontrolled development of the criminal offense of domestic violence is increasing, it can be caused by incorrect type of criminal sanctions selected and specified. There are several clauses in the Act can not be implemented because of legal sanctions that do not fit and there is no implementation regulation, such as home safe and alternative housing for victims of domestic violence. In addition, by a system of alternative sanctions contained in Act No. 23 of 2004 for the community in general lay in the field of law can lead to misinterpretation which those who commit domestic violence can opt for sanctions if they do not want to jail then be able to pay a fine only then they will be free from the bondage of the law. In addition, the inclusion of a maximum sanction without specifying any minimum limit may result in legal uncertainty. The perpetrator could have been just sentenced with a minimum of the minimum and lightweight for victims who are not comparable to the acts committed by the offender, so that victims are reluctant to denounce acts of domestic violence that happened considered ultimately only be a waste of time and can not fulfill a sense of justice victim.

The method used in this research using normative research is descriptive qualitative analysis, the research study was conducted using the existing regulations. This study is a literature, the research of secondary data, as well as the research study was conducted using data, organizing data, sorted them into units that can be managed, synthesize, search and find patterns, find what is learned, and decide what can be told to others. ${ }^{3}$ The data have been collected directly through interviews arranged systematically to further analyzed qualitatively to describe the realities that exist in the community, using legal theories, concepts of law and legal doctrine relating to the matter being investigated.

According to Achmad Ali is not quite right, because no matter what the relationship between the purpose of the law is a legal function of a relationship that is very erat.that first to note, of course, is the purpose of the law, because only the stipulation of what the objectives of the law, we can also determine the functions to be executed laws in order to achieve its objectives. ${ }^{4}$

From this background, this paper is intended to analyze the criminal law policy formulation in the context of tackling the crime of domestic violence. Deeper search of the criminal provisions in the Act No. 23 of 2004 on the Elimination of Domestic Violence by analyzing to a complaint as well as the relationship between the

\footnotetext{
${ }^{3}$ Lexy J. Moleong 2004 Metodologi Penelitian Kualitatif Edisi Revisi Remaja Rosdakarya Bandung p.68.

${ }^{4}$ Achmad Ali 1997 Menguak Takbir Hukum PT. RajaGrafindo Persada Jakarta p. 55
} 
application of criminal sanctions and the purpose of punishment contained in it which is a crucial point in determining the criminal political planning strategy. Determining the purpose of punishment can be the basis for determining the way, means or actions that will be used in the context of tackling the crime of domestic violence. Policy establishes criminal sanctions what is considered the best for the purpose, at least closer to the goal, can not be separated from the issue of the selection of various alternative sanctions. Problems selecting various alternatives to obtain any criminal who considered the best, most precise, the most worthy of the most successful or effective is a problem that is not easy.

Based on the fact mentioned above need to be researched on "Application of Criminal Sanction Policy Against Crime Perpetrators of Domestic Violence."

Formulation Of The Problems are How to policy formulation of the crime of domestic violence?; How the application of criminal sanctions against perpetrators of criminal acts of violence in the home? Constraints are faced judges in the application of criminal sanctions against perpetrators of the crime of domestic violence and efforts to overcome it?

\section{Results And Discussion}

\subsection{Policy Formulation Crime of Domestic Violence}

Violence in the home (domestic violence) tends to be done by men in the age group who are young, not working, not in the bonds of legal marriage, the possibility of ever witnessed domestic violence in childhood, as well as the problem of psychiatry that vary from depression to substance abuse. Some other conditions that require attention to the possibility of domestic violence is a problem related to drugs and alcohol, the situation with regard to the state of stress and depression. Many perpetrators of domestic violence to violence under the influence of alcohol. However, offenders who commit violence in a conscious taking a larger proportion. Perpetrators of domestic violence can be divided into three types:

- Emotional cyclically volatile perpetrators, Domestic violence perpetrators of this type has a dependency on the existence of a partner. In itself has developed a pattern of escalating emotions followed by aggressive action against the couple. When the actors start with psychological violence, the violence can lead to severe physical abuse.

- Overcontrolled perpetratorsThe perpetrators of this type is the group which is in itself have formed pattern of control that lead to control psychological than physical violence.

- Psychopathic perpetrators, Actors in itself does not form an emotional connection or sense of remorse, and tend to be involved also in the violence between men and other criminal behavior. ${ }^{5}$

\footnotetext{
${ }^{5}$ Core Group Modul Konseling bagi Pelaku Kekerasan dalam Rumah Tangga Mitra Perempuan Workshop Jakarta 27 Juni 2008 p.7.
} 


\subsection{Criminal Sanctions Against Crime Perpetrators of Domestic Violence}

Application of criminal sanctions is the final part of the criminal justice system after the investigation and prosecution. After their reports on domestic violence investigators to conduct investigation and apply them in the investigation report and then handed over to the public prosecutor to be making charges on the basis of the investigation report of the investigator. After the indictment is deemed sufficient prosecutors will bring the case to court to be proven in court about what is indicted by the public prosecutor if the charges proved after going through a long process of evidence, the judge will impose sentence. Verdict the judge's ruling can be free, loose, and criminal prosecution. The next stage of the judicial process or legal concretization is a stage or stages of the application or the judiciary.

\subsection{Obstacles-Facing Justice In Criminal Sanctions Application Against Crime Perpetrators of Domestic Violence and Attempts to Overcome}

In every step towards a change and improvement often get let or hindrance. So is the problem of domestic violence, even though it is made of a special law that can be used to handle cases of domestic violence, but in fact the judge handling criminal cases of domestic violence, many findconstraints, as follows: ${ }^{6}$

- The absence of witnesses cause hearing be postponed, so that the proceedings so that the proceedings be longer than scheduled.

- Absence of legal counsel also cause hearing was postponed from the trial process has gone backwards longer than scheduled,

- The absence of a post mortem result in the judge adjourned the hearing, to include post mortem beforehand.

- Judge difficult to prove because there were no witnesses who saw directly, and also sometimes victims of domestic violence and perpetrators still love each other, so that judges convict when the weight will result in divorce.

Efforts to overcome the obstacles that arise in dealing with the crime of domestic violence:

- Handling and settlement of cases of domestic violence that does not result in illness or impediment to perform daily activities pursued through penal mediation first, if not forwarded to court achieved.

- If the witness is not present, then the prosecutor will call again, if it had been called twice and still not present, the public prosecutor can bring witnesses by force.

- When legal advisors are unable to attend, the judge will be reminded that legal counsel be present or to delegate its power to the other legal counsel.

- If the witness victim and perpetrator still love each other, then the judge will decide the case with lighter, for their consideration ease.

\section{Closing}

\subsection{Conclusion}

\footnotetext{
${ }^{6}$ Interview with a judge of Kornel Sian SH.M.Hum. date. 17 February 2018.
} 
- Formulatif policy against criminal acts of domestic violence set out in Chapter VIII of Act No. 23 of 2994 Article 44 of physical violence, violence phisikis Article 45, Article 46, 47, 48 on sexual violence and Article 49 of penelantarkan. Besides, as a result of acts of domestic violence do not lead to a result in the form of illness or impediment to perform their daily activities determined as to a complaint as referred to in Article 51 (physical abuse), Article 52 (psychological violence), and Article 53 (sexual violence committed by a husband or wife). Law on the Elimination of Domestic Violence threat embracing system that is alternative sentence imposed is the form of imprisonment or fines with minimum and maximum rules.

- The application of criminal sanctions against perpetrators of criminal acts of domestic violence committed by the judge after going through the process of proving to the charges the prosecutor. Starting from proven facts deeds of witnesses, then the fact juridical considerations and ease further aggravating the new verdict. Verdict the judge's ruling can be free, loose, and criminal prosecution. In the judge's decision to convict under the threat of punishment maximal, rare cases shall be punished in accordance with the maximum threat of chapter violated.

- Constraints faced by judges in the application of criminal sanctions against perpetrators of criminal acts of domestic violence are:

- The absence of witnesses cause hearing be postponed, so that the proceedings so that the proceedings be longer than scheduled.

- Absence of legal counsel also cause hearing was postponed from the trial process has gone backwards longer than scheduled.

- The absence of a post mortem result in the judge adjourned the hearing, to include post mortem beforehand.

- Judge difficult to prove because there were no witnesses who saw directly, and also sometimes victims of domestic violence and perpetrators still love each other, so that judges convict when the weight will result in divorce.

\subsection{Suggestion}

- Need a review of the Law on the Elimination of Domestic Violence such as the criminalization of an act, the nature to a complaint on several criminal acts because there are some criminal acts of domestic violence that is more appropriate to include in the offense usual for the protection of human rights and justice ,

- In addition to the sanctions maximal need the inclusion of more assertive in terms of the minimum limit of the imposition of criminal sanctions either in prison or a fine for lack of certainty of the law, and the nature of alternative sanctions in the Law on Elimination of Domestic Violence should be considered to use a system of cumulative alternatives for when using the alternative system just for the crime of domestic violence are relatively heavy it is not fair to the victim, where the actors can be free from imprisonment by paying the fine, so that the victims feel unsafe.

\section{Bibliography}

[1] Achmad Ali 1997 Menguak Takbir Hukum RajaGrafindo Persada Jakarta 
[2] Core Group Modul Konseling bagi Pelaku Kekerasan dalam Rumah Tangga Mitra Perempuan Workshop Jakarta

[3] Lexy J. Moleong 2004 Metodologi Penelitian Kualitatif Edisi Revisi Remaja Rosdakarya Bandung

[4] Act of 1945.

[5] The Code of Penal (Penal Code)

[6] The Code of Criminal Procedure (Criminal Procedure Code)

[7] Act No. 23 of 2004 on the Elimination of Domestic Violence. 